University of Chicago Law School

Chicago Unbound

Public Law and Legal Theory Working Papers

Working Papers

2015

\title{
Using Experiments to Test the Effectiveness of Human Rights Treaties
}

Adam S. Chilton

Follow this and additional works at: https://chicagounbound.uchicago.edu/public_law_and_legal_theory

Part of the Law Commons

Chicago Unbound includes both works in progress and final versions of articles. Please be aware that a more recent version of this article may be available on Chicago Unbound, SSRN or elsewhere.

\section{Recommended Citation}

Adam S. Chilton, "Using Experiments to Test the Effectiveness of Human Rights Treaties" (University of Chicago Public Law \& Legal Theory Working Paper No. 533, 2015).

This Working Paper is brought to you for free and open access by the Working Papers at Chicago Unbound. It has been accepted for inclusion in Public Law and Legal Theory Working Papers by an authorized administrator of Chicago Unbound. For more information, please contact unbound@law.uchicago.edu. 


\section{CHICAGO}

PUblic LAW AND Legal THEORY WORKING PAPER No. 533

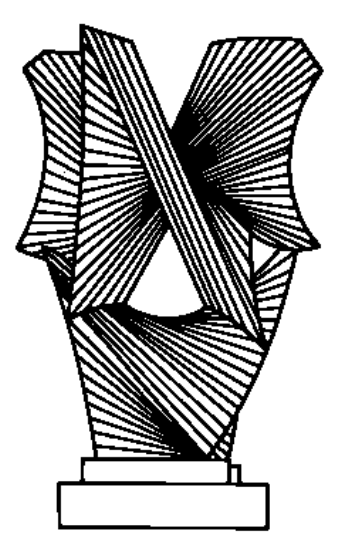

\section{USING EXPERIMENTS TO TEST THE EFFECTIVENESS OF HUMAN RIGHTS TREATIES}

Adam S. Chilton

\section{THE LAW SCHOOL THE UNIVERSITY OF CHICAGO}

June 2015

This paper can be downloaded without charge at the Public Law and Legal Theory Working Paper Series: http://www.law.uchicago.edu/academics/publiclaw/index.html and The Social Science Research Network Electronic Paper Collection. 


\title{
Using Experiments to Test the Effectiveness of Human Rights Treaties
}

\author{
Adam S. Chilton*
}

June 2, 2015

\begin{abstract}
International human rights law is a field concerned with causality. While scholars in other fields argue about how laws can be changed to maximize their effectiveness, scholars of international human rights law still regularly debate whether the major international agreements have had any effect on state behavior. Part of the reason that this threshold question is still contested is that there are a number of barriers to causal inference that make answering it with observational data incredibly difficult. Given these obstacles to using observational data, and the importance of the topic, scholars have begun to use experimental methods to study the effects of commitments to human rights agreements. This paper discusses the motivations behind the limited experimental work on human rights, the mechanisms that are being tested, and the findings of this emerging literature.
\end{abstract}

\footnotetext{
*Assistant Professor of Law, University of Chicago Law School. Email: adamchilton@uchicago.edu. This paper was prepared for the "International Law as Behavior" Conference organized by the American Society of International Law and the University of Georgia School of Law. I would like to thank participants in that conference and Katherina Linos for helpful comments. I would also like to thank Vera Shikhelman and Katie Bass for research assistance, and the Baker Scholars Fund at the University of Chicago Law School for financial support.
} 


\section{Introduction}

International human rights law is a field concerned with causality. While scholars in other fields argue about how laws can be changed to maximize their effectiveness, scholars of international human rights law still regularly debate whether major international agreements have had any effect on state behavior. Some scholars have examined empirical records and concluded that under the right conditions that the ratification of human rights treaties is associated with improved human rights practices, ${ }^{1}$ but others have found that the ratification of human rights treaties does not have any influence on the likelihood that states will violate human rights. ${ }^{2}$

One thing that scholars agree on, however, is that if international human rights treaties were to change state behavior, it would not be because of the usual mechanism that drives compliance with international law: reciprocity. ${ }^{3}$ This is because one states' failure to respect the rights of its citizens cannot be corrected by another state reciprocally violating the rights of its own citizens. As a result, scholars have examined other mechanisms-including domestic politics, empathetic enforcement by powerful states, pressure from international treaty bodies, and the influence of non-governmental organizations - that may lead ratification of human rights agreements to result in changes to state behavior. After over a decade of empirical research on the effectiveness of human rights treaties, however, there is disagreement on whether each of these alternative mechanisms leads to improved rights practices.

This lack of consensus is in part due to the substantial obstacles that stand in the way of using observational data to study the causal effect of human rights treaties on state practices. ${ }^{4}$ Perhaps the most difficult of these obstacles to overcome is the fact that

${ }^{1}$ For research that concludes that human rights treaties improve human rights practices, see Yonatan Lupu, Best Evidence: The Role of Information in Domestic Judicial Enforcement of International Human Rights Agreements, 67 INT'L ORG. 469 (2013); Yonatan Lupu, Legislative Veto Players and the Effects of International Human Rights Agreements, AM. J. POL. SCI. (forthcoming 2015); Daniel W. Hill, Estimating the Effects of Human Rights Treaties on State Behavior, 72 J. POL. 1161 (2010); BETH A. SIMMONS, MOBILIZING FOR HUMAN Rights: INTERNATIONAL LAW IN DOMESTIC POLITICS (2009).

${ }^{2}$ For research that concludes that human rights treaties either have no (or at least a very small) effect on human rights practices, see, e.g., Daniel W. Hill, Jr. \& Zachary M. Jones, An Empirical Evaluation of Explanations for State Repression, 108 AM. POL. SCI. REV. 661 (2014); ERIC A. POSNER, THE TwILIGHT OF INTERNATIONAL HumAN Rights LAW (2014); Emilie M. Hafner-Burton \& Kiyoteru Tsutsui, Human Rights in a Globalizing World: The Paradox of Empty promises, 110 AM. J. SoC. 1373 (2005); Eric. Neumayer, Do International Human Rights Treaties Improve Respect for Human Rights?, 49 J. CONFLICT RESOL. 925 (2005); Oona Hathaway, Do Human Rights Treaties Make a Difference?, 111YALE L. J. 1935 (2002); Linda Camp Keith, The United Nations International Covenant on Civil and Political Rights: Does It Make A Difference in Human Rights Behavior?, 36 J. PEACE RES. 95 (1999).

3 See Simmons, supra note 2 ("Human rights regimes do not involve reciprocal compliance . . . No government is likely to alter its own rights practice to reciprocate for abuses elsewhere.”); POSNER, supra note 2, at 79 ("In the case of ordinary treaties, the main reason that states comply with their obligations is that they fear that if they do not, other treaty parties will violate their own obligations . . . this logic does not easily carry over to human rights treaties.").

4 The difficulties that arise when trying to empirically test compliance with human rights treaties have been well document. For a general overview, see Adam S. Chilton \& Dustin Tingley, Why the Study of International Law Needs Experiments, 52 COLUM. J. TRANSNAT'L L. 173 (2013). For a discussion focused on the problems posed by selection bias, see Yonatan Lupu, The Informative Power of Treaty Commitment: Using 
states are not randomly assigned commitments to human rights treaties, but instead select agreements based on their expected behavior. There is near universal ratification of the major human rights agreements, and most states have also subjected themselves to a series of overlapping international and domestic legal obligations that all seek to protect human rights. Furthermore, convincing evidence has recently emerged showing that the data used by researchers to measure human rights practices is systematically biased. ${ }^{5} \mathrm{It}$ has proven difficult enough to design an observational study that accounts for one of these problems, but designing a study that accounts for all of them simultaneously has so far proven to be close to impossible.

Given these obstacles to using observational data, and the importance of the topic, scholars have begun to use experimental methods to study the effects of commitments to human rights agreements. This is because experimental studies can be designed to test the plausibility of the mechanisms theorized as ways that the ratification of human rights treaties may change state behavior. Although experimental methods are unlikely to definitively establish whether international treaties improve human rights outcomes, the handful of experimental studies conducted to date have found that information on commitments to international agreements does have a modest impact on public opinion. ${ }^{6}$ By doing so, these studies have provided some qualified support for the theorized mechanisms through which treaties may improve human rights.

There are, however, several reasons why the experiments conducted to date have extremely limited generalizability. This is not only because of the general problem that subjects often behave differently in experimental settings than they do in the real world, but also because the human rights experiments that have been conducted to date have almost exclusively relied on surveys administered to samples of Americans. As a result, although the evidence produce by these studies is informative, the evidence does not offer any conclusive answers on whether human rights treaties change state behavior.

That said, these early studies have demonstrated that using experimental methods to study human rights may be able to help bring new evidence to this important debate. Future work should build upon this foundation by expanding: the countries that experiments are conducted in; the topics that are studied; and the type of experiments being conducted. By building on existing studies in this way, experimental research on

the Spatial Model to Address Selection Effects, 57 AM. J. POL. SCI. 912 (2013). For a discussion of the bias in efforts to measure human rights violations, see Christopher J. Fariss, Respect for Human Rights has Improved Over Time: Modeling the Changing Standard of Accountability, 108 AM. POL. SCI. REV. 297 (2014). For critical comments of approaches that have been used in the literature, see Eric A. Posner, Some Skeptical Comments on Beth Simmons's "Mobilizing for Human Rights," 44 NYU J. INT'L L. \& POL. 819 (2012).

5 See Fariss, supra note 4.

${ }^{6}$ Experiments studying international human rights law include: Adam S. Chilton, The Influence of International Human Rights Agreements on Public Opinion: An Experimental Study, 15 CHI. J. INT'L L. 110 (2014); Geoffrey P.R Wallace, Martial Law? Military Experience, International Law, and Support for Torture, 58 INT'L STUD. Q. 501 (2014); Geoffrey P.R Wallace, International Law and Public Attitudes Toward Torture: An Experimental Study, 67 INT’L ORG. 105 (2013); Michael Tomz \& Jessica Weeks, Human Rights, Democracy, and International Conflict, Working Paper (2013); Tonya L. Putnam \& Jacob N. Shapiro, Does International Law Affect Willingness to Punish Foreign Human Rights Abusers?, Working Paper (2009); Michael Tomz, Reputation and the Effect of International Law on Preferences and Beliefs, Working Paper (2008). 
human rights may be able to provide crucial evidence that supplements what has been produced using observational research methods.

This paper proceeds as follows. Part II discusses mechanisms that may lead states to improve their human rights practices as a result of signing human rights agreements. Part III summarizes the evidence from observational studies on whether those mechanisms have led states to improve their human rights practices. Part IV outlines why observational studies face difficulties trying to empirically test the effects of human rights treaties. Part V presents experimental studies that have tried to examine the effect of human rights agreements. Part VI discusses future directions that experimental research on human rights should take.

\section{Theories of Compliance}

A central question in the study of international law is whether states change their behavior because of commitments to international agreements. ${ }^{7}$ This question has taken on unique importance in the human rights context because the mechanism that drives compliance in many areas of international law-reciprocity-is not present. $^{8}$ In most areas of international law, the logical response to State A breaking a commitment is for State B to apply pressure on State A to change its behavior by reciprocating. ${ }^{9}$ For example, if State A were to violate an investment agreement by blocking firms from State $\mathrm{B}$ from acquiring their domestic companies, State B can respond by doing the same thing to firms from State A. ${ }^{10}$ In the human rights context, however, the same logic does not hold. ${ }^{11}$ Unlike investment agreements, if State A were to torture its citizens in violation of an international human rights treaty, State B will not try to convince State A to change course by torturing its own citizens. The implication is that although it is possible that international human rights treaties have helped to improve human rights practices, it is not because of the possibility of reciprocity. Instead, for commitments to human rights treaties to produce changes in state behavior, it would have to be through mechanisms other than reciprocity.

${ }^{7}$ For an example of the debate, compare Abram Chayes \& Antonia Handler Chayes, On Compliance, 47 InT'L Org. 175 (1993) with George W. Downs, David M. Rocke, \& Peter N. Barsoom, Is the Good News About Compliance Good News About Cooperation?, 50 INT'L ORG. 379 (1996).

${ }^{8}$ For longer discussions of the role of reciprocity in compliance with international law, see JACK L. Goldsmith \& Eric A. Posner. The Limits of International LaW (2005); Eric A. Posner \& ALAN O. SYKES, ECONOMIC FOUNDATIONS OF INTERNATIONAL LAW (2013). In an example of an empirical work that explores the effects of reciprocity, JAMES D. MORROW, ORDER WITHIN ANARCHY: THE LAWS OF WAR AS AN INTERNATIONAL INSTITUTION (2014) shows that reciprocity drives compliance with the laws of war.

9 See POSNER, supra note 2 , at 79.

10 See, e.g., Dustin Tingley, Christopher Xu, Adam S. Chilton \& Helen Milner, The Political Economy of Inward FDI: Opposition to Chinese Mergers and Acquisitions, 8 CHINESE J. INT'L POL. 27 (2015) (finding that the United States is more likely to block attempts by Chinese companies to acquire American firms when China has previously blocked American companies in the same industries).

11 See POSNER, supra note 2, at 79-82; SIMMONS, supra note 1, at 122. 
Figure 1 illustrates some of the mechanisms through which commitments to international human rights treaties could result in changes to state behavior. The solid lines represent the commitments that states make to human rights treaties. ${ }^{12}$ The dashed lines then represent four mechanisms that might create pressure for states to change their human rights practices after having signed a human rights treaty: (1) ratification changes the domestic politics of countries that are at least partially democratic; (2) other countries coercing states to comply with their commitments; (3) treaty bodies pressuring the state to improve its human rights practices; and (4) Non-Governmental Organizations ("NGO") advocating for compliance.

\section{Figure 1: Mechanisms Through Which Human Rights Treaties}

\section{May Change State Behavior}

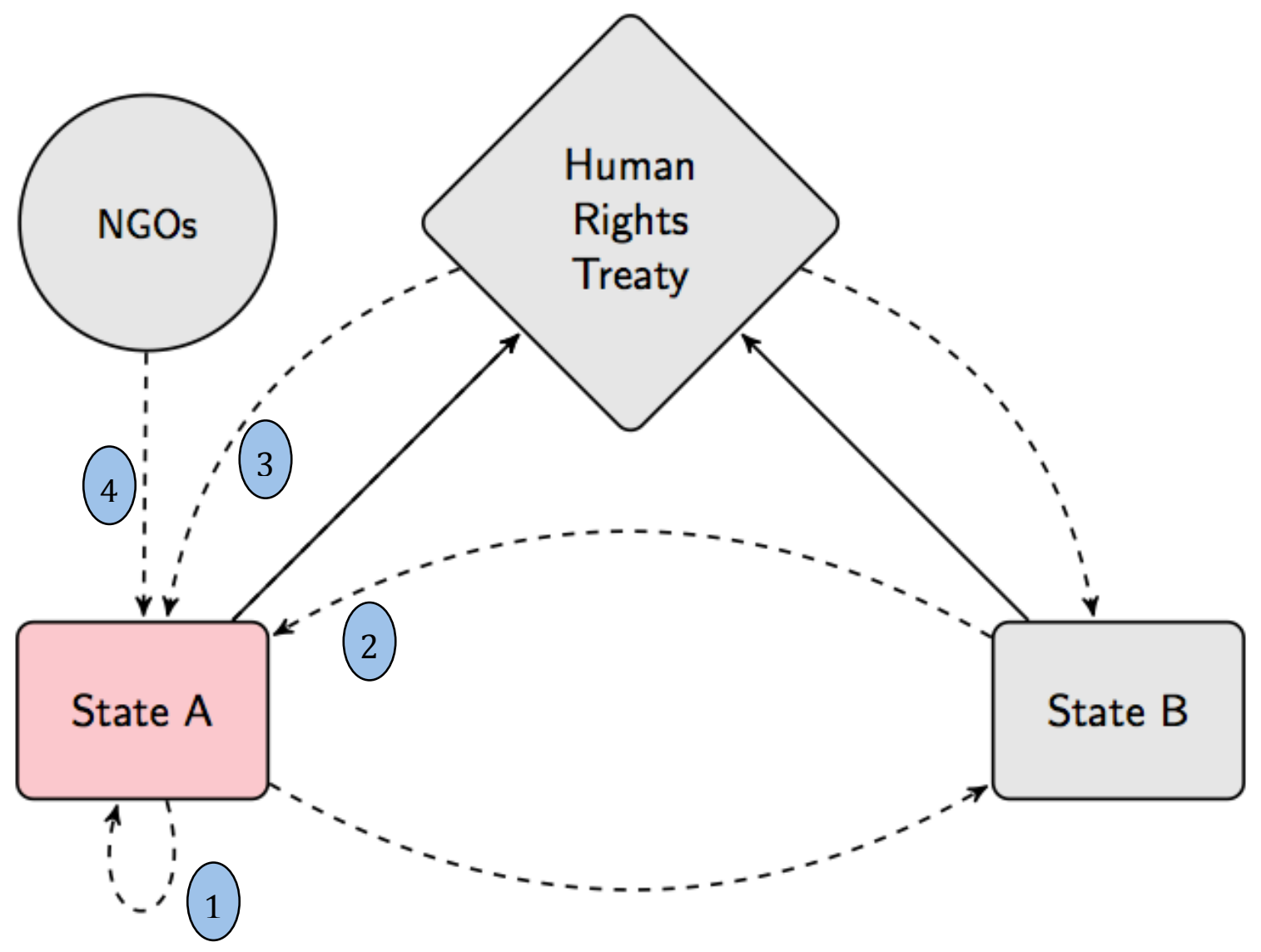

12 The exact reason that states choose to commit to human rights treaties is a subject of debate. For example, it may be the case that states make commitments because of domestic considerations, or it may be the case that states sign agreements because they are persuaded to do so by other states with either carrots or sticks. For discussions of the topic, see POSNER, supra note 2, at 59-68; POSNER \& SYKES, supra note 8, at 202-206; SIMMONS, supra note 1, at 57-111. For a recent empirical consideration of this topic, see Richard A. Nielsen \& Beth A. Simmons, Rewards for Ratification: Payoffs for Participating in the International Human Rights Regime, 59 INT'L STUD. Q. 179 (2015). 
1. Domestic Politics - The primary mechanism that has been theorized as driving compliance with human rights treaties - illustrated by the dashed loop below State A-is that ratification of human rights treaties may change the domestic political landscape of partially democratic countries in ways that make it easier for activists and opposition political parties to lobby for improved rights practices. ${ }^{13}$ For all but the most powerful states, new human rights treaties create exogenous shocks to countries' domestic agendas that force governments to decide whether to sign the treaty and make a public commitment to human rights. This shock may create an opening for domestic groups to lobby for improved rights practice, and if the agreement is signed, it may improve the ability of domestic groups to pressure the government to live up to the commitments it made. This pressure may come in many forms. For example, it may be human rights activists bringing litigation to try and have the courts pressure the government to bring human rights practices into compliance with the government, or it may be opposition political parties attacking the government for failure to live up to prior international commitments.

2. Empathetic Enforcement - A second mechanism that may drive compliance with human rights treaties - illustrated by the dashed lines between countries - is "empathetic enforcement" by powerful states. ${ }^{14}$ Although states are not obligated to apply strong pressure on repressive states to comply with human rights agreements, it is possible that they might choose to do so. This pressure could conceivably come in many forms. For example, developed countries might condition foreign aid upon recipient states improving human rights practices, or be more likely to militarily intervene in countries that violate human rights commitments they have made. If powerful states were more likely to apply these forms of pressure against repressive states that had previously committed to human rights treaties, this would be one way that treaty commitment could lead to improve rights practices.

3. Treaty Body Pressure - A third mechanism that may drive compliance with human rights agreements - represented by the dashed line from the treaty to the statesis pressure applied by the international treaty bodies themselves. ${ }^{15}$ By voluntarily signing onto international human rights agreements, states subject themselves to monitoring by treaty bodies. The treaty bodies then have the power to produce reports that recommend ways for the states to improve human rights, or to issue statements chastising states for failure to live up to their commitments. Although the international treaty bodies cannot back up these statements with explicit sanctions, the reports may indirectly influence human rights practices.

13 For a discussion of the ways that ratifying human rights agreements may influence domestic politics and thus lead to changes in state behavior, see Simmons, supra note 2, at 125-148.

14 I borrow the term "empathetic enforcement" from Beth Simmons. See Simmons, supra note 1, at 116. This mechanism is also often referred to simply as "coercion" by powerful states. For a discussion of the mechanism and examples of where it has been used, see GOLDSMITH \& POSNER, supra note 6, at $115-117$.

${ }^{15}$ It is worth noting that scholars have largely been skeptical that this mechanism could actually lead states to change their behavior. See POSNER, supra note 2, at 95-104; EMILIE M. HAFNER-BURTON, MAKING HUMAN RightS A REALITY (2013), at 44-66; SIMMONS, supra note 1, at 121-125. 
4. NGO Advocacy - A fourth mechanism that may lead states to improve human rights practices after ratifying international agreements - represented by the dashed line from the NGOs to State A-is the influence of non-governmental organizations. ${ }^{16}$ There are a large number of NGOs dedicated to trying to improve human rights practices around the world. This includes organizations that cover a broad range of issues like Amnesty International and Human Rights Watch, as well as organizations focused on specific issue areas. These organizations use a range of tactics to pressure governments to improve their rights practices. These tactics include filing reports with treaty bodies, lobbying powerful governments to pressure repressive states, and naming and shaming states that violate human rights. If NGOs are more effective at changing the human rights practices of states that have previously ratified international human rights treaties, it would be one way that a ratification may result in changes in state behavior.

\section{Evidence from Observational Studies}

Despite years of scholarship researching the four mechanisms discussed in the previous section, it is still disputed whether any of the four are viable channels through which treaty commitments may result in improved human rights practices. In this section, I will briefly discuss empirical research that has used observational data to test whether these four mechanisms has caused states to change their behavior. ${ }^{17}$

First, empirical research has examined whether domestic political mechanisms may lead states to improve their human rights practices after ratifying international treaties. In the most prominent research testing this theory, the political scientist Beth Simmons tested the effectiveness of thirteen human rights treaties. ${ }^{18}$ Simmons found evidence that ratification was associated with improved human rights practices for seven of the thirteen agreements. Simmons' research did not, however, suggest that the effectiveness of ratification was consistent for all countries. Instead, Simmons found that ratification of human rights treaties is not associated with improved human rights in stable democracies or stable autocracies, but is associated with better rights practices in transitioning democracies. According to Simmons, the reason that transitioning democracies changes their behavior after ratifying human rights treaties is that the existence of the agreement helps domestic groups pressure their governments to be more respectful of rights. In addition to Simmons' research, two recent empirical studies

\footnotetext{
${ }^{16}$ For a discussion of the role that NGOs can play in promoting human rights, see HAFNERBURTON, supra note 15, at 151-163. For skepticism over this possibility, see POSNER, supra note 2, at 82.

17 A complete survey of the empirical human rights literature is beyond the scope of this chapter. For a short introduction to the empirical literature on human rights, see Adam S. Chilton \& Eric A. Posner, The Influence of History on States' Compliance with Human Rights Obligations, 56 VA. J. INT'L L. (forthcoming 2015). For more thorough reviews, see Emilie M. Hafner-Burton, A Social Science of Human Rights, 51 J. PEACE RES. 273 (2014); Emilie M. Hafner-Burton, International Regimes for Human Rights, 15 AnN. REV. POL. SCI. 265 (2012); Gregory Shaffer \& Tom Ginsburg, The Empirical Turn in International Legal Scholarship, 106 AM. J. INT’L L. 1, 19-25 (2012); Beth A. Simmons, Treaty Compliance and Violation, 13 ANN. REV. POL. SCI. 273 (2010).

18 SIMMONS, supra note 1.
} 
by the political scientist Yonathan Lupu have used sophisticated empirical techniques to test whether domestic mechanisms increase the effectiveness of human rights treaties. Lupu's studies have found that compliance with the ICCPR has increased when there are more veto points in the states legislature, ${ }^{19}$ or when there is an independent judiciary that can evaluate claims that certain rights are being violated. ${ }^{20}$ Although Simmons' and Lupu's research has produced perhaps the most promising evidence that committing to human rights treaties may drive states to change their behavior, it is worth noting that it has been suggested that these studies at best show that ratification has made a marginal improvement in rights practices for a small number of countries on a handful of issues. ${ }^{21}$

Second, empirical research has tested whether empathetic enforcement might cause states to improve their human rights behavior. One body of research testing this theory has examined whether aid donors have punished states that violate human rights by withholding aid. ${ }^{22}$ Although that line of scholarship has produced mixed results, in the most recent research on the topic, the political scientist Richard Nielsen found that states only selectively sanction human rights violators. That is, although aid is sometimes withheld from states that violate human rights, "[d]onors seem willing to abandon human rights norms when their friends and allies violate human rights." ${ }^{23}$ Based on this finding and other similar research, scholars have largely been skeptical that states would actually improve their human rights practices because of rewards or punishments from more powerful countries. ${ }^{24}$

Third, there has been limited research trying to test whether pressure from human rights treaty bodies leads states to improve their human rights practices. Since human rights bodies do not have any strong enforcement powers and countries do not uniformly take their obligations to report to human rights bodies seriously, ${ }^{25}$ it is perhaps unsurprising that few scholars have tried to link activities of human rights bodies to improved rights practices. In one study on the topic, James Lebovic and Erik Voeten tested whether resolutions condemning a state's human rights practices passed by the United Nations Commissions on Human Rights ("UNCHR”) resulted in that state

${ }^{19}$ Lupu, Legislative Veto Players, supra note 1.

${ }^{20}$ Lupu, Best Evidence, supra note 1. Lupu's claim is that the presence of an independent judiciary increases respect for the ICCPR for civil rights, but not for physical integrity rights. The theory Lupu puts forward to explain this finding is that an independent judiciary can police rights violations for issue areas where the standards, proof, or evidence production costs are low. For another empirical paper that considers the effectiveness of domestic legal institutions on compliance with human rights agreements, see Emilia Justyna Powell \& Jeffery K. Stanton, Domestic Judicial Institutions and Human Rights Treaty Violations, 53 INT'L STUD. Q. 149 (2009).

21 Posner, supra note 2, at 76-78.

22 Richard A Nielsen, Rewarding Human Rights? Selective Aid Sanctions Against Repressive States. 57 INT’L STUD. Q. 891, 791-92 (2013).

${ }^{23} \mathrm{Id}$. at 791.

24 See SIMMONS, supra note 1, at 116 ("If we are looking for empathetic enforcement [of human rights treaties] from other countries, we will be looking in vain for a long time."); Posner, supra note 2, at 80-81 ("Even powerful countries often cannot exert sufficient pressure on a human rights violator to cause it to improve its behavior, because the target of sanctions can often retaliate by improving its ties with the sanctioning countries' rivals.").

25 See Cosette Creamer \& Beth A. Simmons, Ratification, Reporting and Rights: Quality of Participation in the Convention Against Torture, HuM. RTS. Q. (forthcoming 2015). 
receiving lower levels of foreign aid. ${ }^{26}$ Their study found that resolutions condemning human rights practices are associated with states receiving lower amounts of aid from multilateral organizations like the World Bank, but that resolutions condemning human rights practices are not associated with aggregate bilateral aid. Even if UNCHR resolutions result in lower foreign aid, however, it does not necessarily follow that the resolutions cause improvements in human rights. As a result, despite this finding, Beth Simmons has argued that "[n]o one has shown any significant external enforcement behind the provisions of international human rights treaties of a kind that might plausibly account for the patterns of compliance observed across a number of rights areas." 27

Fourth, a handful of empirical studies have tried to test whether pressure from NGO's has led to improved human rights practices. This research has focused on whether efforts to "name and shame" countries for violation of human rights has led to better practices. In what is perhaps the most widely cited study on the subject, Emilie Hafner-Burton found that efforts to spotlight human rights violations by NGOs are associated with increased repression. ${ }^{28}$ Hafner-Burton explains this finding by arguing that oppressive governments have incentive to crack down on opposition groups after they are empowered by the attention created by international organizations. In contrast to Hafner-Burton's finding, Anna Schrimpf found that there is likely no relationship (but perhaps a positive relationship) between NGO attention and human rights practices. ${ }^{29}$ Finally, in related research, Judith Kelley \& Beth Simmons found that including states on "watch lists" is associated with those states being likely to then criminalize human trafficking. ${ }^{30}$

\section{Barriers to Causal Inference with Observational Data}

As the proceeding discussion hopefully made clear, a consensus view among empirical researchers has not emerged on the question of whether ratification of international human rights agreements improves state behavior. Although this is likely in part because empirical scholarship on international law is relatively new, it is also because there are a number of factors that make it incredibly difficult to study the causal effects of human rights treaties using observational data. ${ }^{31}$

${ }^{26}$ James H. Lebovic \& Erik Voeten. The Cost of Shame: International Organizations and foreign Aid in the Punishing of Human Rights Violations, 46 J. PEACE RES. 79 (2009).

${ }^{27}$ Simmons, supra note 17, at 291.

${ }^{28}$ Emilie Hafner-Burton, Sticks and Stones: Naming and Shaming the Human Enforcement Problem, 62 INT'L ORG. 689 (2008)

29 Anna Schrimpf, Does INGO Activism Improve Human Rights Practices? Evidence from a Multi-Issue Analysis (Working Paper 2014).

${ }^{30}$ Judith G. Kelley \& Beth A. Simmons, Politics by Number: Indicators as Social Pressure in International Relations, 59 AM. J. POL. SCI. 55 (2015).

${ }^{31}$ The following discussion is based on Chilton \& Tingely, supra note 4. The discussion in Chilton \& Tingley uses human rights law and the International Humanitarian Law to make a broader point about empirical research in international law, and also develops the arguments discussed here more fully. Additionally, the data in this originally presented in Chilton \& Tingley, supra note 4. 
First, observational research on human rights treaties has difficulty accounting for selection bias. Selection bias exists when the assignment of a treatment variable is systematically related to the dependent variable of interest. For example, if the subjects given Drug $X$ in a clinical trial were picked to receive the drug because they were the healthiest subjects in the group, any positive effect of the drug may be attributable to the fact that the receipt of the Drug X (the treatment) was related to likely health outcomes (the dependent variable). The same problem exists in studying human rights treaties. Countries do not enter into treaties randomly. Instead, countries voluntarily choose to enter into human rights agreements based on their preferences and planned policies. To be clear, it might be the case that countries decide to enter into the agreement when they don't plan on complying, or that they enter into the agreements when they do. Either is problematic for empirical research. Although empirical researchers have developed strategies to try and account for this selection bias, ${ }^{32}$ ultimately there is only so much that can be done given the fact that countries voluntarily select into human rights regimes and thus any later human rights practices are endogenous to the decision to ratify the treaties.

Figure 2: Number of Countries Party to Major Human Rights Treaties

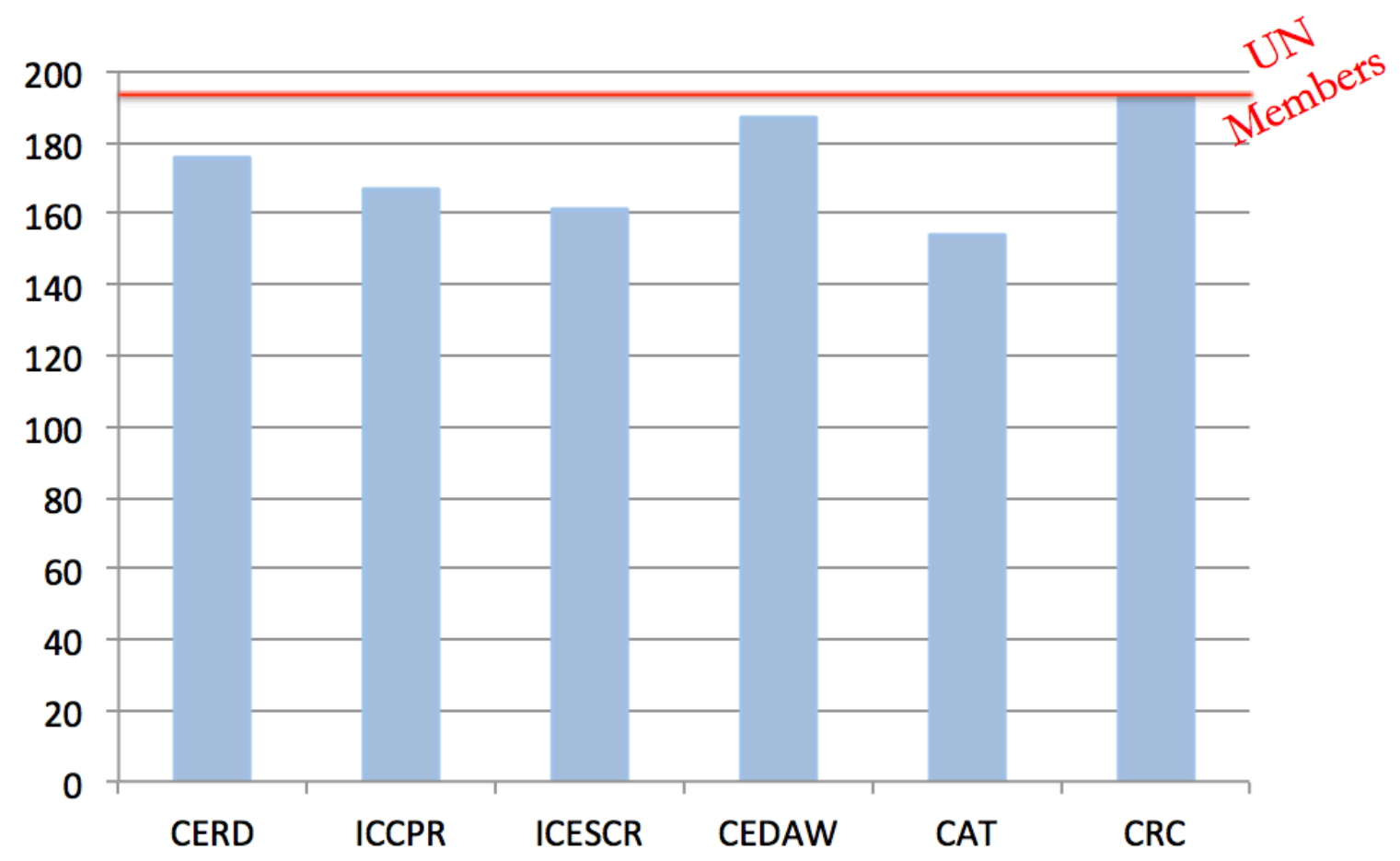

Second, even if it were possible to account for selection bias, a basic requirement of causal inference is variance. Simply put, there must be variance in the explanatory variable of interest to be able to assess the impact that it has on a given dependent

\footnotetext{
${ }^{32}$ For an excellent discussion of the ways that researchers have tried to account for selection bias while studying international law, see Lupu, supra note 4.
} 
variable. For example, if everyone that contracted a new disease was given Drug $X$, it would be impossible to know the effectiveness of Drug $X$ (which is exactly why clinical trials randomly give some subjects placebos). This basic requirement of causal inference is a major hurdle for studying human rights treaties because there is very little variance in applicability of the major international human rights agreements (and no variance in the applicability of the parts of human rights law that are considered part of customary international law). As Figure 2 shows, nearly every country has signed onto the major human rights treaties. To further illustrate this point, the red line is the number of countries that are currently members of the United Nations. Since there are very few countries that are not party to the major human rights agreements, and countries that are not party to the agreement are likely not representative, it is thus very difficult to understand the effectiveness of these agreements on human rights practices.

Figure 3: Ratification History of Major Human Rights Agreements

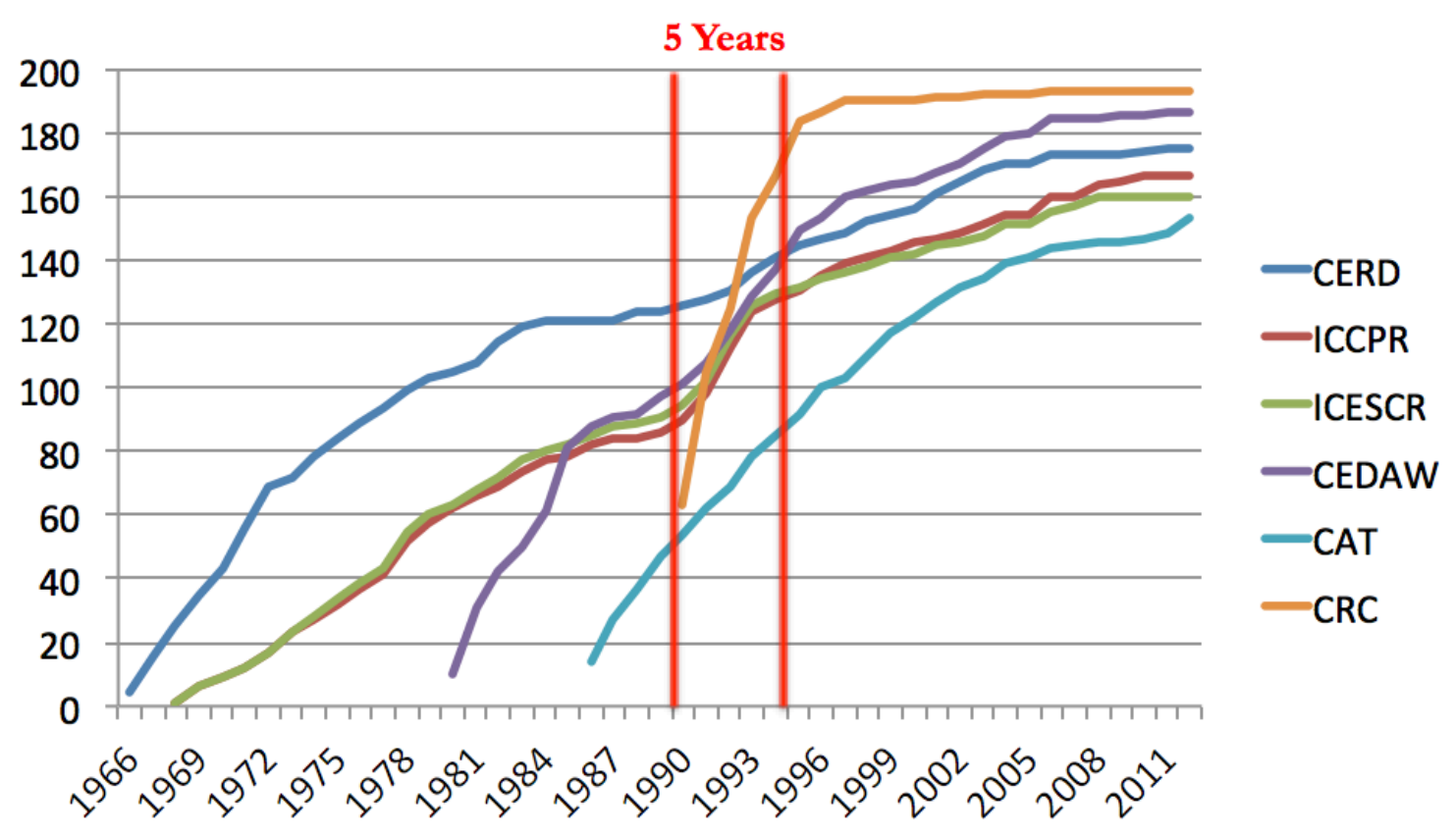

Third, the current lack of variance in ratification of major human rights treaties would not be as much of a problem if historically there had been variance in which countries were party to the treaties. If that were the case, it would be possible to study the period between when the treaty had opened for ratification and when nearly all countries joined the agreements. For the first major human rights treaties, this was the case. As Figure 3 shows, countries continued to ratify the Convention on Elimination of Racial Discrimination (CERD), the International Covenant on Civil and Political Rights (ICCPR), and the International Covenant on Economic, Social, and Cultural Rights 
(ICESCR) for the entire later half of the twentieth century. ${ }^{33}$ As Figure 3 also shows, however, more recent human rights treaties have been ratified incredibly quickly. For example, the most recent major human rights treaty-the Convention on the Rights of the Child (CRC)-became widely adopted in about five years. ${ }^{34}$ Although these increasingly short ratification windows may be a positive development for the human rights movement, they are problematic for human rights researchers that need longer windows before widespread ratification to study.

Figure 4: Countries that Have Made Commitments to Eliminate Torture

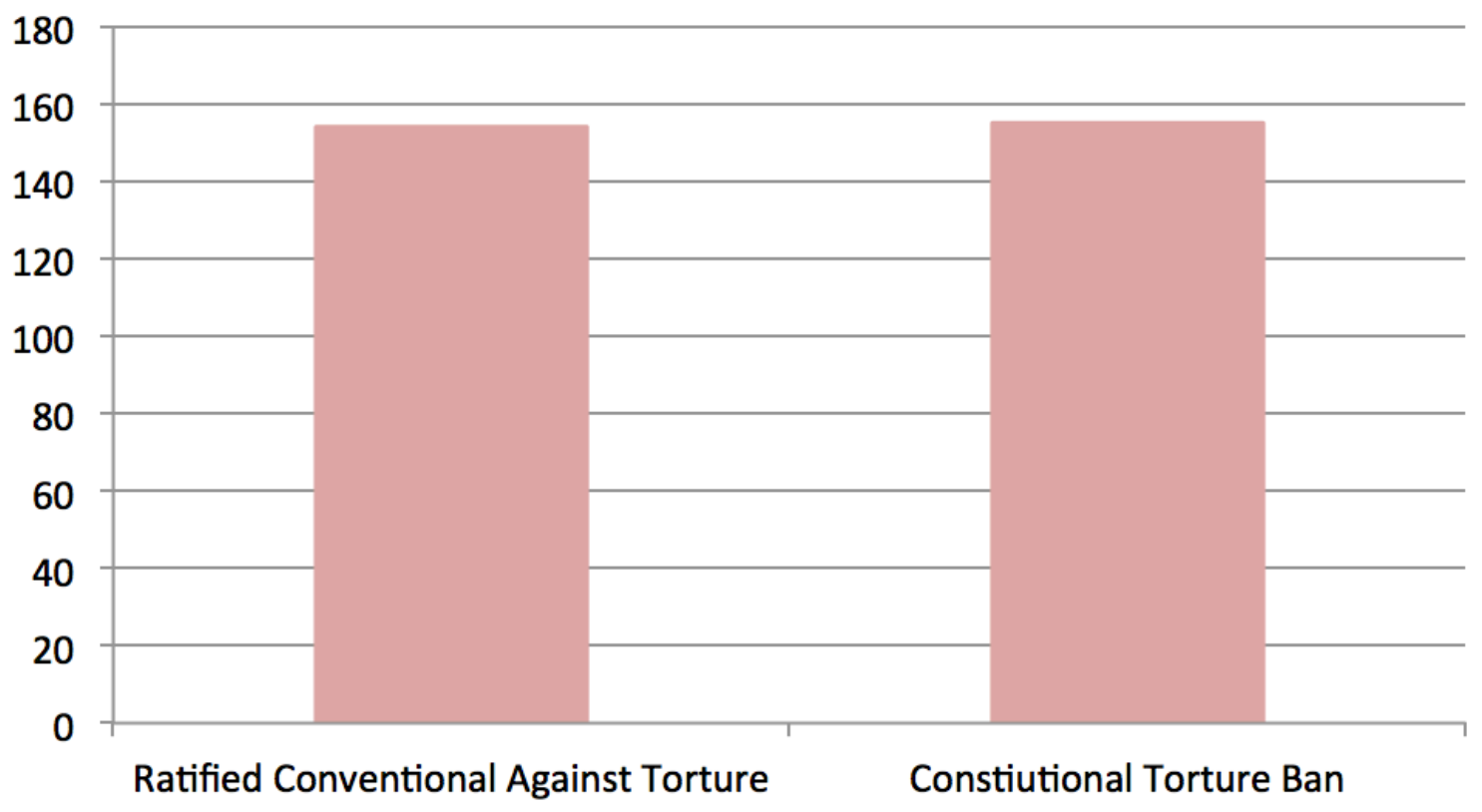

Fourth, another difficulty with conducting empirical research on the effectiveness of human rights treaties is that countries frequently have overlapping legal obligations. The problem is that it is only possible to understand the effect of a given variable if it is possible to isolate it from other variables that may be driving the outcome of interest. For example, if everyone that contracted a new disease were given both Drug $X$ and Drug $Y$, it would be impossible to isolate the effects of Drug $X$ and the effects of Drug $Y$ (not to mention the effect of their interaction). The same problem often exists with international legal commitments. Countries often have signed multiple agreements that regulate human rights practices, have joined multiple organizations that monitor human rights compliance, and also have domestic laws that prohibit the same conduct as the

${ }^{33}$ It is important to note that the number of countries in the world also dramatically increased during this period. As a result, Figure 3 may suggest there was more variance in early years that there actually was. For example, in the early 1980's when roughly 120 countries were party to the CERD, roughly 150 countries were members of the United Nations.

${ }^{34}$ In another example, 159 countries have signed the Convention on the Rights of Persons with Disabilities (CRPD) since it opened for signature in 2007. 
international agreement. To illustrate this point, Figure 4 shows the number of countries that have signed the Convention Against Torture (CAT) and the number of countries that have provisions in their constitutions that prohibit torture. ${ }^{35}$ As the figure shows, there is nearly the same number of countries with each restriction as of 2015. These kinds of overlaps can make it difficult to tell whether changes (for better or worse) in human rights practices are attribute to international treaties or other sources of law.

Fifth, beyond the previous four concerns related to the ratification of human rights treaties, it is also the case that there are frequently only flawed measures of human rights practices available to use as dependent variables. Human rights treaties seek to protect a large number of rights. In fact, as Figure 5 shows, the number of rights protected by individual treaties ranges from 11 to 58. Currently, however, there is only data available for a handful of rights available for a large numbers of countries. The result is that it is difficult to know whether a given treaty has improved rights because there are not good measures for all of the rights that any given treaty tries to protect.

Figure 5: Number of Rights Protected in Major Human Rights Agreements

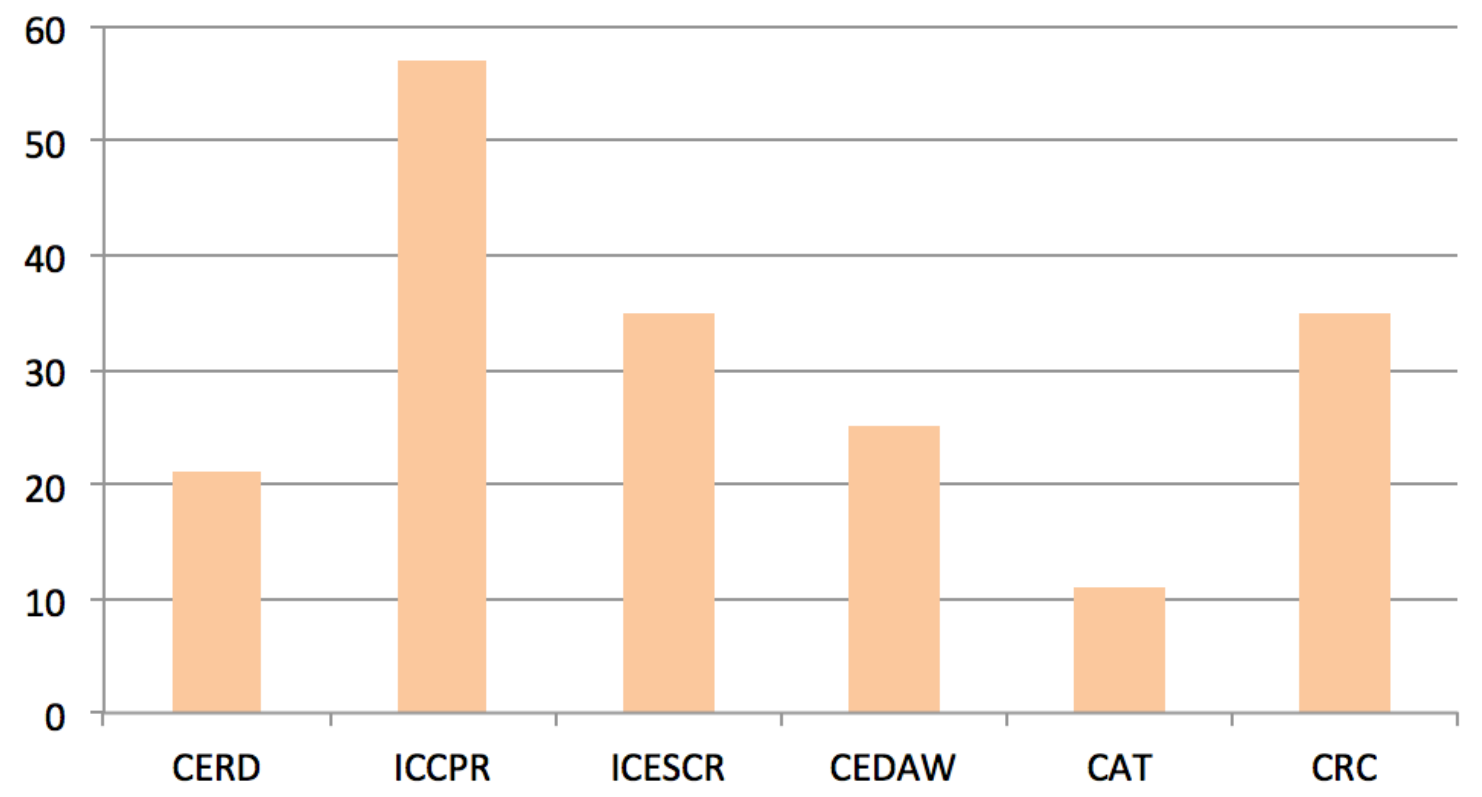

Moreover, even if there was unbiased data for one of these rights—say the right of freedom of speech - it might be the case that the treaty improves protection for that right while making things worse for another dozen rights. That said, it is likely the case that all of the current data sources are biased. Recent research has shown that the most widely used dataset for human rights—the CIRI dataset-is systematically biased

${ }^{35}$ For information on the data on constitutional torture prohibitions used in this figure, see Adam S. Chilton \& Mila Versteeg, The Failure of Constitutional Torture Probibitions, Working Paper (2015). 
because reporting standards have changed over time. ${ }^{36}$ This not only calls into question the results of studies that have relied on the CIRI data, ${ }^{37}$ but also suggests that any other research that uses data on rights practices based on reports may be biased as well. Since the data on human rights practices has shown to be biased and only covers a few rights, taken together these facts should make it clear that it is difficult to use conventional methods of empirical research to study the effectiveness of human rights agreements.

\section{Experimental Evidence}

One advantage of experimental research is that experiments can be designed to help test the mechanisms discussed in Part II that have been theorized as driving compliance with human rights agreements while account for the barriers to inference discussed in Part V. Of course, my claim is not that experiments can address all of these problems at once. ${ }^{38}$ Instead, they can help to bring new evidence to help evaluate the effectiveness of human rights agreements. To date, experimental studies have been designed to test the plausibility of three of the four mechanisms that were previously outlined: (1) Domestic Politics, (2) Empathetic Enforcement, and (3) Treaty Body Pressure.

1. Domestic Politics - There have been at least two experiments conducted that tested whether prior commitments to international agreements increased support for policy reforms that would make a state comply with its human rights obligations. In the first experiment designed to test this mechanism, Wallace (2013) conducted a survey on American adults to determine whether information on prior commitments to international law decreased support for torture. ${ }^{39}$ The survey told respondents that the United States often captures combatants from the opposing side during conflicts, and that those combatants may have information on future attacks. The survey further told respondents that some officials believe that using interrogation methods that include torture on the combatants may be a useful way to obtain information on future attacks. The survey then randomly told half of the sample that those interrogation methods

36 See Fariss, supra note 4. The CIRI dataset uses State Department and Amnesty International Reports to code the human rights practices of countries on a 3-point scale. Fariss, however, uses a sophisticated empirical model to show that these widely used scores are biased because the reporting standards have changed over time. Although Fariss also has created an unbiased single measure of "repression" that can be used as a dependent variable, it is only one variable that does not cover all of the rights that treaties try to protect.

37 This is not a criticism of scholars that have used the CIRI data in their research (which I readily admit to being one of) — using the CIRI data is a completely reasonable decision given the data source with the broadest coverage available. After Fariss, supra note 4, however, scholars should be aware of the limitations with the CIRI data and any other dataset that uses reports on human rights to code countries.

38 Of course, experimental research has problems of its own-the most notable of which being external validity. The limitations of experimental research are briefly discussed in Part VI.

39 Wallace, International Law and Public Attitudes Toward Torture, supra note 6. A companion paper also analyzes the results of this experiment, but focuses on whether there is a differential treatment effect for respondents with military experience. See Wallace, Martial Law, supra note 6. 
would violate international law and treaties that the United States had previously committed to. ${ }^{40}$ After reading this information, respondents were asked whether they supported the use of interrogation techniques that include torture. Wallace found that respondents given information international law treatment were $6 \%$ less supportive of using torture than the respondents that did not receive the information. This survey suggests that even on an issue where people have strong views, information on international law can have a statistically significant effect on the views of Americans.

The second study designed to test the Domestic Politics mechanism is Chilton (2014). ${ }^{41}$ Chilton (2014) also conducted a survey on a sample of American adults to test the effect of information on international law, but made two changes to the design used by Wallace (2013). First, the survey focused on a purely domestic topic to reduce the possibility that respondents changed their view in light of international law because they thought that retaliations may result from non-compliance. Second, the survey include a placebo treatment to see whether the legal commitments, instead of the general idea of human rights, is what lowered support for violations of human rights treaties. The survey specifically focused on the use of solitary confinement in American prisons. Respondents were told that solitary confinement is often used in American prisons, and that supporters of the practice argue that it's necessary to maintain prisons discipline. There were then three randomly assigned treatments: the control group was not given any information on human rights; the placebo group was told that critics argue that the use of solitary confinement "violates the human rights of the prisoners held in solitary confinement"; the international law group was told that critics argue that the use of solitary confinement "violates international human rights treaties that the United States has signed." The idea is that the placebo group invoked the idea of human rights generally without relying on a specific legal commitment, thus making it possible whether the existence of specific treaties - as opposed to general norms-is what influences opinion. The results of the survey suggested that there was no difference between the control and placebo group in their level of support for using solitary confinement, but that there was a small but statistically significant difference with the international law treatment. Respondents that received that treatment were roughly $4 \%$ more likely to support reforming the use of solitary confinement.

2. Empathetic Enforcement - Several experiments have tested whether information on international law makes respondents more likely to support efforts to change the policies of states that violate human rights. For example Putnam and Shapiro (2013), tested respondents' willingness to support economic sanctions against a foreign country because of its human rights violations. ${ }^{42}$ In a survey of American adults, Putnam and Shapiro told respondents about the use of forced labor in Myanmar. After being given varying amounts of information on the severity of the human rights violations in Myanmar, respondents were also given different information about the status of international law. The experiment suggested that information on international law

40 This summary only discusses on the primary manipulation in Wallace's paper, but the paper also include two other treatments and a related second experiment. See Wallace, International Law and Public Attitudes Toward Torture, supra note 6.

${ }^{41}$ Chilton, supra note 6.

42 Putnam \& Shaprio supra note 6. 
increased support for government sanctions, but did not increase respondents' willingness to say that they would personally boycott goods from Myanmar. Although the complete findings of the experiment were mixed, the authors did find qualified support for the idea that respondents learned that human rights violations were against international law. ${ }^{43}$

In another experiment that tests support for empathetic enforcement, Tomz and Weeks (2013) examined factors that influence support for military intervention. ${ }^{44}$ In the survey, respondents were told about a hypothetical country developing nuclear weapons. Respondents were randomly told about the countries regime type-that is, whether or not it was democratic - as well as about the countries human rights record. Half of the respondents were told that "The country does not violate human rights; it does not imprison or torture its citizens because of their beliefs", while the other half were told that "The country violates human rights; it imprisons or tortures some of its citizens because of their believes." The respondents were then asked about their willingness to support military strikes against the country. The results suggest that respondents were dramatically more likely to support military strikes when the country violated human rights. Specifically, the experiment revealed a $23 \%$ increase in support for military strikes against democracies that violate human rights, and a $16 \%$ increase in support military strikes against autocracies that violate human rights.

3. Treaty Body Pressure - At least one experiment has tested whether treaty body pressure increases support for reforms aimed at improving human rights. Anjum, Chilton, \& Usman (2015) conducted an experiment in Pakistan that tested whether learning that policy reforms aimed at improving women's rights were proposed by the United Nations increases support for the reforms. ${ }^{45}$ In the experiment, roughly 600 subjects were recruited in Pakistan to take an in person survey on women's rights. The respondents were asked whether they supported four reforms that the United Nations Committee on the Elimination of Discrimination Against Women recommended that Pakistan should implement. Half of the subjects were told that the reforms were proposed by the United Nations, while half of the subjects were not told who proposed the reforms. The results of the experiment revealed that learning that the United Nations supported the reforms increased support for them. The results of the experiment thus provide some evidence that when the United Nations supports a policy reform, it might increase its domestic support.

43 In a related earlier study, Tomz, supra note 6 , also tested whether respondents were willing to support sanctions in response to human rights violations in Myanmar. The difference, however, is that in the international law treatment respondents were told that the sanctions would violate international law. Tomz found that information on international law decreased support for the use of sanctions by $17 \%$.

44 Tomz \& Weeks, supra note 6.

45 Gulnaz Anjum, Adam S. Chilton, \& Zahid Usman, The Effect of Endorsement from International Organizations on Support for Women's Rights: Evidence from an Experiment in Pakistan, Working Paper (2015). 


\section{Future Research \& Concluding Thoughts}

Although the experimental research on human rights has suggested that information on human rights agreements may be able to change public opinion, there are serious limitations to the studies that have been conducted to date. Most notably, the fact that nearly all of the experiments on human rights have been conducted using vignette studies with respondents in the United States seriously limits the generalizability of the findings. ${ }^{46}$ This method of research is still in its infancy, however, and could learn a great deal from the more developed experimental literatures in development economics, American politics, and international relations. I will briefly outline three ways that future experimental studies on human rights could improve on prior research.

First, experiments should be conducted in transitioning democracies. There is little evidence to suggest that human rights treaties have improved the rights practices of stable democracies or stable autocracies. Instead, the best available evidence suggests that human rights agreements are most likely to change the behavior of developing democracies. ${ }^{47}$ That is, countries like those in Eastern Europe or Central America that are not well-established, stable democracies, but that have moved towards democracy in the last few decades. To date, however, nearly all of the experiments on the effectiveness of human rights have been conducted in the United States. ${ }^{48}$ This is a major shortcoming of the small experimental literature on human rights because the United States is not only a stable democracy, but also because Americans may have idiosyncratic views towards international human rights agreements. There have been a large number of experiments conducted by political scientists in developing countries in the last several years, ${ }^{49}$ and there is a great deal that scholars interested in international human rights law could learn from these efforts.

Second, experimental research should explore a wider range of topics. For better or worse, ${ }^{50}$ there are dozens of rights that are protected by international human rights agreements. ${ }^{51}$ One of the advantages of experimental research is that a study can be designed to test whether international commitments can increase support for providing any right that is included within a treaty. Since observational studies can only test the effectiveness of rights where cross-country data is available, this is one comparative advantage of experimental research. This advantage should be leveraged, and studies

46 But see Anjum, Chilton, \& Usman, supra note 45.

47 SIMMONS, supra note 1, at 152-153.

48 See Chilton, supra note 6; Wallace, supra note 6; Putnam \& Shaprio supra note 6; Tomz \& Weeks, supra note 6.

49 See, e.g., Sarah Sunn Bush \& Amaney A. Jamal, Anti-Americanism, Authoritarian Politics, and Attitudes about Women's Representation: Evidence from a Survey Experiment in Jordan, INT'L STUD. Q. (forthcoming 2014); Graeme Blair, Kosuke Imai \& Jason Lyall, Explaining Support for Combatants in Wartime: A Survey Experiment in Afghanistan, 107 AM. POL. SCI. REV. 679 (2013); Graeme Blair, Christine Fair, Neil Malhotra, \& Jacob N. Shapiro, Poverty and Support for Militant Politics: Evidence from Pakistan, 57 AM. J. POL. SCI. 30 (2013).

50 Posner, supra note 2, argues that including too many rights in international agreements may have adverse consequences on rights protections.

51 See Chilton \& Tingley, supra note 4, at 214. 
should be conducted to test whether the impact that information has on international law is conditional on the nature of the right at issue.

Third, scholars conducting experiments on human rights should start to utilize field experiments. Although the survey experiments that have been conducted provide new data on the influence of human rights agreements on public opinion, it is not clear whether those differences in opinion translate into meaningful changes in the respondents' behavior, and in turn, into changes in public policies. Researchers in a number of fields related to international law-including international economic regulation, international relations, and development economics-have begun to conduct field experiments to determine whether experimental interventions result in changes to real world behavior. ${ }^{52}$ These experiments are thus able to reduce the concern that using experimental methods will produce internal valid results, but that they will not have any real-world applicability.

Of course, even if future experimental research on the effectiveness of human rights law moves in the direction that I have outlined, it does not mean that any one study will be able to definitely demonstrate whether human rights treaties have improved human rights chances around the world. Instead, experimental methods can produce evidence that compliments empirical research using observational data. If researchers studying human rights were to begin conducting experiments, it would compliment the evidence that is being produced by other methods. This would make it possible to triangulate on the answer to whether human rights treaties improve respect for rights.

52 See, e.g., Michael G. Findley, Daniel L. Neilesen, \& J.C. Sharman, Using Field Experiments in International Relations: A Randomized Experiment of Anonymous Incorporation, 67 INT'L ORG. 657 (2013); James D. Fearon, Macartan Humphreys \& Jeremy M. Weinstein, Can Development Aid Contribute to Social Cohesion after Civil War? Evidence from a Field Experiment in Post-Conflict Liberia, 99 AM. ECON. REV. 287 (2009); James Habyarimana, Macartan Humphreys, Daniel N. Posner \& Jeremy M. Weinstein, Why Does Ethnic Diversity Undermine Public Goods Provision?, 101 AM. POL. SCI. REV. 709 (2007). 
Readers with comments may address them to:

Professor Adam S. Chilton

University of Chicago Law School

1111 East 60th Street

Chicago, IL 60637

adamchilton@uchicago.edu 


\section{The University of Chicago Law School Public Law and Legal Theory Working Paper Series}

For a listing of papers 1-400 please go to http://www.law.uchicago.edu/publications/papers/publiclaw.

401. Gary Becker, François Ewald, and Bernard Harcourt, "Becker on Ewald on Foucault on Becker” American Neoliberalism and Michel Foucauilt’s 1979 Birth of Biopolitics Lectures, September 2012

402. M. Todd Henderson, Voice versus Exit in Health Care Policy, October 2012

403. Aziz Z. Huq, Enforcing (but Not Defending) “Unconstitutional” Laws, October 2012

404. Lee Anne Fennell, Resource Access Costs, October 2012

405. Brian Leiter, Legal Realisms, Old and New, October 2012

406. Tom Ginsburg, Daniel Lnasberg-Rodriguez, and Mila Versteeg, When to Overthrow Your Government: The Right to Resist in the World's Constitutions, November 2012

407. Brian Leiter and Alex Langlinais, The Methodology of Legal Philosophy, November 2012

408. Alison L. LaCroix, The Lawyer's Library in the Early American Republic, November 2012

409. Alison L. LaCroix, Eavesdropping on the Vox Populi, November 2012

410. Alison L. LaCroix, On Being “Bound Thereby,” November 2012

411. Alison L. LaCroix, What If Madison had Won? Imagining a Constitution World of Legislative Supremacy, November 2012

412. Jonathan S. Masur and Eric A. Posner, Unemployment and Regulatory Policy, December 2012

413. Alison LaCroix, Historical Gloss: A Primer, January 2013

414. Jennifer Nou, Agency Self-Insulation under Presidential Review, January 2013

415. Aziz Z. Huq, Removal as a Political Question, February 2013

416. Adam B. Cox and Thomas J. Miles, Policing Immigration, February 2013

417. Anup Malani and Jonathan S. Masur, Raising the Stakes in Patent Cases, February 2013

418. Ariel Porat and Lior Strahilevits, Personalizing Default Rules and Disclosure with Big

Data, February 2013

419. Douglas G. Baird and Anthony J. Casey, Bankruptcy Step Zero, February 2013

420. Alison L. LaCroix, The Interbellum Constitution and the Spending Power, March 2013

421. Lior Jacob Strahilevitz, Toward a Positive Theory of Privacy Law, March 2013

422. Eric A. Posner and Adrian Vermeule, Inside or Outside the System? March 2013

423. Nicholas G. Stephanopoulos, The Consequences of Consequentialist Criteria, March 2013

424. Aziz Z. Huq, The Social Production of National Security, March 2013

425. Aziz Z. Huq, Federalism, Liberty, and Risk in NIFB v. Sebelius, April 2013

426. Lee Anne Fennell, Property in Housing, April 2013

427. Lee Anne Fennell, Crowdsourcing Land Use, April 2013

428. William H. J. Hubbard, An Empiritcal Study of the Effect of Shady Grove v. Allstate on Forum Shopping in the New York Courts, May 2013

429. Daniel Abebe and Aziz Z. Huq, Foreign Affairs Federalism: A Revisionist Approach, May 2013

430. Albert W. Alschuler, Lafler and Frye: Two Small Band-Aids for a Festering Wound, June 2013

431. Tom Ginsburg, Jonathan S. Masur, and Richard H. McAdams, Libertarian Paternalism, Path Dependence, and Temporary Law, June 2013

432. Aziz Z. Huq, Tiers of Scrutiny in Enumerated Powers Jurisprudence, June 2013 
433. Bernard Harcourt, Beccaria's On Crimes and Punishments: A Mirror of the History of the Foundations of Modern Criminal Law, July 2013

434. Zachary Elkins, Tom Ginsburg, and Beth Simmons, Getting to Rights: Treaty

Ratification, Constitutional Convergence, and Human Rights Practice, July 2013

435. Christopher Buccafusco and Jonathan S. Masur, Innovation and Incarceration: An Economic Analysis of Criminal Intellectual Property Law, July 2013

436. Rosalind Dixon and Tom Ginsburg, The South African Constitutional Court and SocioEconomic Rights as 'Insurance Swaps', August 2013

437. Bernard E. Harcourt, The Collapse of the Harm Principle Redux: On Same-Sex Marriage, the Supreme Court's Opinion in United States v. Windsor, John Stuart Mill's essay On Liberty (1859), and H.L.A. Hart's Modern Harm Principle, August 2013

438. Brian Leiter, Nietzsche against the Philosophical Canon, April 2013

439. Sital Kalantry, Women in Prison in Argentina: Causes, Conditions, and Consequences, May 2013

440. Becker and Foucault on Crime and Punishment, A Conversation with Gary Becker, François Ewald, and Bernard Harcourt: The Second Session, September 2013

441. Daniel Abebe, One Voice or Many? The Political Question Doctrine and Acoustic Dissonance in Foreign Affairs, September 2013

442. Brian Leiter, Why Legal Positivism (Again)? September 2013

443. Nicholas Stephanopoulos, Elections and Alignment, September 2013

444. Elizabeth Chorvat, Taxation and Liquidity: Evidence from Retirement Savings, September 2013

445. Elizabeth Chorvat, Looking Through' Corporate Expatriations for Buried Intangibles, September 2013

446. William H. J. Hubbard, A Fresh Look at Plausibility Pleading, March 2015

447. Tom Ginsburg, Nick Foti, and Daniel Rockmore, "We the Peoples": The Global Origins of Constitutional Preambles, March 2014

448. Lee Anne Fennell and Eduardo M. Peñalver, Exactions Creep, December 2013

449. Lee Anne Fennell, Forcings, December 2013

450. Jose Antonio Cheibub, Zachary Elkins, and Tom Ginsburg, Beyond Presidentialism and Parliamentarism, December 2013

451. Nicholas Stephanopoulos, The South after Shelby County, October 2013

452. Lisa Bernstein, Trade Usage in the Courts: The Flawed Conceptual and Evidentiary Basis of Article 2's Incorporation Strategy, November 2013

453. Tom Ginsburg, Political Constraints on International Courts, December 2013

454. Roger Allan Ford, Patent Invalidity versus Noninfringement, December 2013

455. M. Todd Henderson and William H.J. Hubbard, Do Judges Follow the Law? An Empirical Test of Congressional Control over Judicial Behavior, January 2014

456. Aziz Z. Huq, Does the Logic of Collective Action Explain Federalism Doctrine? January 2014

457. Alison L. LaCroix, The Shadow Powers of Article I, January 2014

458. Eric A. Posner and Alan O. Sykes, Voting Rules in International Organizations, January 2014

459. John Rappaport, Second-Order Regulation of Law Enforcement, April 2015

460. Nuno Garoupa and Tom Ginsburg, Judicial Roles in Nonjudicial Functions, February 2014

461. Aziz Huq, Standing for the Structural Constitution, February 2014

462. Jennifer Nou, Sub-regulating Elections, February 2014

463. Albert W. Alschuler, Terrible Tools for Prosecutors: Notes on Senator Leahy's Proposal to "Fix" Skilling v. United States, February 2014

464. Aziz Z. Huq, Libertarian Separation of Powers, February 2014 
465. Brian Leiter, Preface to the Paperback Edition of Why Tolerate Religion? February 2014

466. Jonathan S. Masur and Lisa Larrimore Ouellette, Deference Mistakes, March 2014

467. Eric A. Posner, Martii Koskenniemi on Human Rights: An Empirical Perspective, March 2014

468. Tom Ginsburg and Alberto Simpser, Introduction, chapter 1 of Constitutions in Authoritarian Regimes, April 2014

469. Aziz Z. Huq, Habeas and the Roberts Court, April 2014

470. Aziz Z. Huq, The Function of Article V, April 2014

471. Aziz Z. Huq, Coasean Bargaining over the Structural Constitution, April 2014

472. Tom Ginsburg and James Melton, Does the Constitutional Amendment Rule Matter at All? Amendment Cultures and the Challenges of Measuring Amendment Difficulty, May 2014

473. Eric A. Posner and E. Glen Weyl, Cost-Benefit Analysis of Financial Regulations: A Response to Criticisms, May 2014

474. Paige A. Epstein, Addressing Minority Vote Dilution Through State Voting Rights Acts, February 2014

475. William Baude, Zombie Federalism, April 2014

476. Albert W. Alschuler, Regarding Re's Revisionism: Notes on "The Due Process Exclusionary Rule", May 2014

477. Dawood I. Ahmed and Tom Ginsburg, Constitutional Islamization and Human Rights: The Surprising Origin and Spread of Islamic Supremacy in Constitutions, May 2014

478. David Weisbach, Distributionally-Weighted Cost Benefit Analysis: Welfare Economics Meets Organizational Design, June 2014

479. William H. J. Hubbard, Nuisance Suits, June 2014

480. Saul Levmore and Ariel Porat, Credible Threats, July 2014

481. Brian Leiter, The Case Against Free Speech, June 2014

482. Brian Leiter, Marx, Law, Ideology, Legal Positivism, July 2014

483. John Rappaport, Unbundling Criminal Trial Rights, April 2015

484. Daniel Abebe, Egypt, Ethiopia, and the Nile: The Economics of International Water Law, August 2014

485. Albert W. Alschuler, Limiting Political Contributions after Mccutcheon, Citizens United, and SpeechNow, August 2014

486. Zachary Elkins, Tom Ginsburg, and James Melton, Comments on Law and Versteeg's "The Declining Influence of the United States Constitution," August 2014

487. William H. J. Hubbard, The Discovery Sombrero, and Other Metaphors for Litigation, September 2014

488. Genevieve Lakier, The Invention of Low-Value Speech, September 2014

489. Lee Anne Fennell and Richard H. McAdams, Fairness in Law and Economics: Introduction, October 2014

490. Thomas J. Miles and Adam B. Cox, Does Immigration Enforcement Reduce Crime? Evidence from 'Secure Communities', October 2014

491. Ariel Porat and Omri Yadlin, A Welfarist Perspective on Lies, May 2015

492. Laura M. Weinrib, Civil Liberties outside the Courts, October 2014

493. Nicholas Stephanopoulos and Eric McGhee, Partisan Gerrymandering and the Efficiency Gap, October 2014

494. Nicholas Stephanopoulos, Aligning Campaign Finance Law, October 2014

495. John Bronsteen, Christopher Buccafusco and Jonathan S. Masur, Well-Being and Public Policy, November 2014

496. Lee Anne Fennell, Agglomerama, December 2014 
497. Avital Mentovich, Aziz Z. Huq, and Moran Cerf, The Psychology of Corporate Rights, December 2014

498. Lee Anne Fennell and Richard H. McAdams, The Distributive Deficit in Law and Economics, January 2015

499. Omri Ben-Shahar and Kyle D. Logue, The Perverse Effects of Subsidized Weather Insurance, May 2015

500. Adam M. Samaha and Lior Jacob Strahilevitz, Don't Ask, Must Tell—and Other Combinations, January 2015

501. Eric A. Posner and Cass R. Sunstein, Institutional Flip-Flops, January 2015

502. Albert W. Alschuler, Criminal Corruption: Why Broad Definitions of Bribery Make Things Worse, January 2015

503. Jonathan S. Masur and Eric A. Posner, Toward a Pigovian State, February 2015

504. Richard H. McAdams, Vengeance, Complicity and Criminal Law in Othello, February 2015

505. Richard H. McAdams, Dhammika Dharmapala, and Nuno Garoupa, The Law of Police, February 2015

506. William Baude, Sharing the Necessary and Proper Clause, November 2014

507. William Baude, State Regulation and the Necessary and Proper Clause, December 2014

508. William Baude, Foreword: The Supreme Court's Shadow Docket, January 2015

509. Lee Fennell, Slicing Spontaneity, February 2015

510. Steven Douglas Smith, Michael B. Rappaport, William Baude, and Stephen E. Sachs, The New and Old Originalism: A Discussion, February 2015

511. Alison L. LaCroix, A Man For All Treasons: Crimes By and Against the Tudor State in the Novels of Hilary Mantel, February 2015

512. Alison L. LaCroix, Continuity in Secession: The Case of the Confederate Constitution, February 2015

513. Adam S. Chilton and Eric A. Posner, The Influence of History on States' Compliance with Human Rights Obligations, March 2015

514. Brian Leiter, Reply to Five Critics of Why Tolerate Religion? August 2014

515. Nicholas Stephanopoulos, Teaching Election Law, September 2014

516. Susan Nevelow Mart and Tom Ginsburg, [Dis-]Informing the People's Discretion: Judicial Deference Under the National Security Exemption of the Freedom of Information Act, November 2014

517. Brian Leiter, The Paradoxes of Public Philosophy, November 2014

518. Nicholas Stephanopoulos, Eric McGhee, and Steven Rogers, The Realities of Electoral Reform, January 2015

519. Brian Leiter, Constitutional Law, Moral Judgment, and the Supreme Court as SuperLegislature, January 2015

520. Nicholas Stephanopoulos, Arizona and Anti-Reform, January 2015

521. Lee Anne Fennell, Do Not Cite or Circulate, February 2015

522. Aziz Z. Huq, The Difficulties of Democratic Mercy, March 2015

523. Aziz Z. Huq, Agency Slack and the Design of Criminal Justice Institutions, March 2015

524. Aziz Z. Huq, Judicial Independence and the Rationing of Constitutional Remedies, March 2015

525. Zachary Clopton, Redundant Public-Private Enforcement, March 2015

526. Nicholas Stephanopoulos, Political Powerlessness, March 2015

527. Brian Leiter, Normativity for Naturalists, March 2015

528. Brian Leiter, Legal Realism and Legal Doctrine, April 2015 
529. Adam S. Chilton and Marin K. Levy, Challenging the Randomness Of Panel Assignment in the Federal Courts of Appeals, December 2014

530. Anthony J. Casey and Eric A. Posner, A Framework for Bailout Regulation, February 2015

531. G. Mitu Gulati and Richard A. Posner, The Management of Staff by Federal Court of Appeals Judges, April 2015

532. Daniel Telech and Brian Leiter, Nietzsche and Moral Psychology, April 2015

533. Adam S. Chilton, Using Experiments to Test the Effectiveness of Human Rights Treaties, June 2015 